\title{
The First Stalin Mass Operation (1927)*
}

\author{
Olga Velikanova \\ University of North Texas \\ Velikanova@unt.edu
}

\begin{abstract}
This article based on new archival documents introduces a new episode of mass operations, which took place in June and July of 1927 and was directed against the broad group of "antiSoviet" forces. It preceded many practices of mass terror of the 1930s with judicial and extralegal mechanisms. The goal of this article is to explain motivations, justifications, and mechanisms of this repressive campaign and to put this episode in the wider context of Soviet terror. Facing the combination of a perceived danger of war and real internal social hostility expressed in broad defeatism, both threatening the perpetuation of their governmental powers, authorities resorted to repressions. The 1927 episode highlights the factor of a perceived threat of war as a crucial motivating element in Soviet repressive tactics.
\end{abstract}

Keywords

popular defeatism; Stalin; repressions; mass operation; extralegality

This article introduces a new episode of mass operation that occurred in June and July of 1927-that fateful year in the emergence of the Stalinist system. This operation targeted a broad group of "anti-Soviet" forces and, with its judicial and extralegal mechanisms, including Article $5^{8}$ of the

\footnotetext{
* This article was made possible by the research grants from the University of North Texas. I am grateful for the feedback I received from the participants in the VIII World Congress of Central and East European Studies in Stockholm in 2010, in the Southern Conference on Slavic Studies in Washington, DC in 2011, and from David Hoffmann and Mark Harrison. The important encouragement I received from Oleg Khlevnyuk. The anonymous reviewers gave immensely valuable comments. Jonathon Savage helped me to prepare this article for publication. Some parts of this article were published in Olga Velikanova, Popular Perception of Soviet Politics in the 1920s. Disenchantment of the Dreamer, 2013, Palgrave Macmillan, and reproduced here with permission of Palgrave Macmillan. The full published version of this publication is available from: $w$ ww.palgrave.com/products/title.aspx?pid=595134.
} 
USSR Criminal Code for counterrevolutionary crimes, put into effect in 1927, was an important step in the formation of mass repression practices.

The current tendency in historiography-studying Soviet state violence politics within its wider contexts, whether European, social, ${ }^{1}$ or chronological $^{2}$ - allows scholars to suggest a view on the nature of Soviet political violence as not so much a product of Marxism and Bolshevism, but rather of the total war experience of 1914-1920. State violence, which played so outsized role in the Soviet system of government, is often placed in relation to modern state instruments of social management that showed their effectiveness in the extraordinary situation of World War I in all combatant countries. ${ }^{3}$ The war showed that modern states had now acquired the technological ability to control their populations at a new level and to direct them toward victory through new forms of mass mobilization, surveillance, registration techniques, ${ }^{4}$ policing, and excisionary state violence. The Bolsheviks, who opposed the whole world with their socialist project, even after the end of the Civil War, understood their position as one of permanent emergency, which legitimized wartime practices, like the suspension of law, mass operations, expropriations, hostage-taking, deportations, and concentration camps, in peacetime. The 1927 mass operation,

1) Paul Hagenloh, Stalin's Police. Public Order and Mass Repressions in the USSR, 1926-1941 (Washington, D.C.: Woodrow Wilson Center Press, 2009) and David R. Shearer, Policing Stalin's Socialism: Repression and Social Order in the Soviet Union, 1924-1953 (New Haven: Yale University Press, 2009) study repressions not solely against political enemies, but also criminals, and speculators.

2) Nicolas Werth, "A State against Its People" in The Black Book of Communism. Crimes, Terror, Repression, Stephane Courtois, Nicholas Werth, et al. (Cambridge, MA, 1999), 132-145; Stephen G. Wheatcroft, "Agency and Terror: Evdokimov and Mass Killing in Stalin's Great Terror," in Australian Journal of Politics and History 53, no. 1 (2007); S. A. Krassil'nikov, A. S. Zuev, "Ssylka v Sibir' v XVII - pervoi polovine XX v." Istoricheskaia Entsiklopedia Sibiri, vol. 3 (Novosibirsk, 2009); Stuart Finkel, "An Intensification of Vigilance. Recent Perspectives on the Institutional History of the Soviet Security Apparatus in the 1920s," Kritika, 5, 2 (Spring 2004) and others expand it to the post-revolutionary decade.

3) Peter Holquist, "State Violence as Technique: The Logic of Violence in Soviet Totalitarianism," in David L. Hoffmann, ed., Stalinism: The Essential Readings (Malden, MA: Blackwell Publishing, 2003); Idem, "What's So Revolutionary about Russian Revolution? State Practices and the New-Style Politics, 1914-21" in Russian Modernity. Politics, Knowledge, Practices, ed. by D. Hoffmann and Y. Kotsonis, (New York: St. Martin's Press, 200o); David L. Hoffmann, Cultivating the Masses. Modern State Practices and Soviet Socialism, 1914-1939 (Ithaca: Cornell University Press, 2011).

4) Peter Holquist, "'Information is the Alpha and Omega of OurWork': Bolshevik Surveillance in its Pan-European Perspective," Journal of Modern History 69, no. 3 (1997). 
which took place in a war-scare situation against a background of mass defeatism, is studied in the context of the persistent application of extrajudicial practices, before and after, as evidence of the emergency model of Stalin's power technology. ${ }^{5}$

In 1927 the situation within different areas of life-political, economic, and social-proved to be very far from the conventional representation of the NEP period as one of social truce. Huge unemployment figures, strikes in the industrial sector, grain strikes in the countryside, food shortages, riots, the introduction of ration cards, banditry, an intraparty struggle between Stalin and Trotsky, and finally the exodus of members from the Communist Party — all of these dangerous developments inside the country coincided with the failure in 1927 of Soviet foreign policy, which had been directed toward igniting world revolution through the Comintern, in China and Britain specifically. The perception by the ruling elite of these challenges at home and abroad as an emergency took the shape of a "war scare."

The panic in the government became evident on January 13, 1927, when at the Moscow party conference, N. I. Bukharin oddly exaggerated the aggressive intentions of the "imperialists," announcing that "war may start any moment in the spring or summer." In the absence of real international threats, what most likely frightened Bukharin was the military coup in Lithuania on December 17, 1926, and the repressions against the communists that followed. Besides the ghost of bloody retribution, the Lithuanian coup could have frightened the Bolsheviks in the context of Pilsudski's coup in Poland in May 1926, which led the Soviets to expect at any moment that western border states would form an anti-USSR bloc with British support. It seems that the Soviet leaders took such a possibility as a certainty, which produced the war scare. Bukharin perceived this foreign threat in the context of internal insecurity: he noted that the monarchist-émigrés cooperating with Britain backed anti-Soviet movements inside the USSR among the Cossacks and in Georgia. As one historian noted, all interwar politics were shaped by "Stalin's obsession with the vulnerability of Soviet frontiers to foreign intervention in support of internal opposition." ${ }^{7}$

This alarm was bolstered when, on February 23, 1927, Britain directed a "warning note" to the Soviet government demanding it stop "anti-British

5) Sheila Fitzpatrick defines Stalinism as "extraordinary times".

6) Pravda, January 13, 1927.

7) Alfred J. Rieber, "Stalin as Foreign Policy-maker," in Sarah Davies and James Harris, ed., Stalin. A New History (Cambridge: Cambridge University Press, 2005), 141. 
propaganda" and military support for the revolution in China under threat of breaking diplomatic relations. Finally, at the end of May, Britain broke trade and diplomatic relations with the USSR. Additionally, the news about mass executions of Communists in China by the Kuomintang as a result of the failed revolutionary movement there probably made the Bolsheviks nervous.

The Soviet press interpreted this diplomatic motion in extraordinarily bellicose terms--as a sure sign of coming war. ${ }^{8}$ A militant mobilization campaign started. On June 1, the VKPb Central Committee called in Pravda for the population to be ready for armed defense of the Soviet power at any moment.

\section{Defeatism}

Society took these events to heart. The January alarmist claims by leaders about a possible war immediately produced hysteria in the Russian markets: peasants made panicked purchases and stopped selling grain to the state. From that moment, tensions inside the country became aggravated, finally culminating in a conflict that summer between the government and society, particularly the peasants. In this crisis, the war scare and mobilization propaganda were the catalysts.

The political mobilization of society by means of propaganda campaign was mostly unsuccessful ${ }^{9}$ and met with controversial responses from the population. Besides a rise in patriotism among youth, the calls for

8) Historiography argues that Stalin consciously exaggerated alarm in order to eliminate party opposition and to concentrate power in his hands. Alfred G. Meyer, "The War Scare of 1927", Soviet Union/Union Sovietique 5, no. 1 (1978); John P. Sontag, "The Soviet War Scare of 1927," The Russian Review 34, no. 1 (1975): 66; N. S. Simonov, "Strengthen the Defense of the Land of Soviets': The 1927 'War Alarm' and its consequences” in Europe-Asia Studies 48, no. 8 (1996); O. Oleinik, "Problemy voennoi ugrozy SSSR v 1927 godu," in Problemy sotsial'no-politicheskogo razvitija rossiiskogo obschestva (Ivanovo, 1992), 50. However, Sheila Fitzpatrick, "The Foreign Threat during the First Five Plan," Soviet Union/Union Sovietique 5, no. 1 (1978) and A. V. Golubev “Esli mir obrushitsia na nashu respubliku” (Moscow: Kuchkovo Pole, 2008) see much deeper reasons for the war scare.

9) Party svodka \#4, October 7, 1927, Rossiiskii Gosudarstvennyi Arkhiv Sotsial'noPoliticheskoi Istorii (RGASPI), f. 17, op. 32, d. 113, 1l. 16, 19, 26, 27; Kenneth Slepyan, "The Limits of Mobilization: Party, State and the 1927 Civil Defense Campaign," Europe-Asia Studies 45, no. 5, (1993). 
mobilization ignited powerful defeatist and anti-Soviet sentiments among many potential conscripts: both workers and peasants. ${ }^{10}$ The authorities (and now historians) could learn from diverse sources, originating from local Communist Party officials, the OGPU, village correspondents, and numerous letters, ${ }^{11}$ that a large part of the population displayed no desire to defend the Soviet government in the event of war. Moreover, the rural populace often threatened, if conscripted, to turn their rifles against the Bolsheviks instead of toward a foreign aggressor. The leaders were well aware that they could face an internal front and mass desertion in the case of war, as happened in the Civil War.

Geographically, the defeatist mood was all encompassing, with the Central region, the North Caucasus, and the Ukraine presenting the largest numbers of defeatist agitation in the summer of 1927. The OGPU registered a total of 7,269 cases in the June-August period, but chekists asserted this data was "far from complete." ${ }^{2}$ This negativity knew neither social nor class restrictions; it flourished within all sectors of society: workers, employees, intelligentsia, with the peasantry the most articulate in their dissent, comprising 69.5 percent of all defeatists. ${ }^{13}$ The OGPU reported the opinions of workers: "In the event of war, workers won't go to war as they themselves have seen the 'niceties' of the Soviet regime, which itself longs to start a war, seeing no exit from a hard situation." "I, like many others, will no longer defend [the country]. There are no more fools. Enough! We defended and what did we get for it? Nothing. Workers live much worse than during the Tsarist regime."14 Workers predicted: "Communists will have to fight on two fronts-against England and the peasants." ${ }^{15}$

10) RGASPI, f. 17, op. 85, d. 289, ll. 2-49; Nicolas Werth, "Rumeurs Defaitistes et Apocalyptiques dens L'URSS des Annees 1920 et 1930," Vingtieme Siecle, Revue d'histoire 71, (2001).

11) A. Y. Livshin, I. B. Orlov, Vlast' i obschestvo: Dialog v pis'mah (Moscow: ROSSPEN, 2002), 180; Idem., Pis'ma vo vlast', 1917-1927 (Moscow: ROSSPEN, 1998); Svetlana Kriukova, Krestianskie Istorii. Rossiiskaia derevnia 1920-kh godov v pis'makh i documentakh (Moscow: ROSSPEN, 2001).

12) Alexei Berelovich, Viktor Danilov, Sovetskaia derevnia glazami VChK-OGPU-NKVD. Dokumenty i materialy, vol. 2 (Moscow: ROSSPEN, 2000) (Hereafter SD), 628-9; RGASPI, f. 17, op. 85 , d. 289 , ll. $18,25,28$.

13) RGASPI, f. 17, op. 85 , d. 289 , l. 21.

14) Infosvodka No 44(165), August 20, 1927, Gosudarstvennyi Arkhiv Rossiiskoi Federatsii (GARF), f. 374, op. 27s, d. 1211, l. 8 ff.

15) RGASPI, f. 17 , op. 85 , d. 289 , ll. 6-7. 
The peasants' negative reactions to the government calls for mobilization were unanimous. The editor of Krest'ianskaia Gazeta, S. Uritsky, in February 1927, summarized the content of thousands of letters to the editor: "Peasants do not want to fight. There is no single letter in favor of war [i.e., defense of the USSR]." ${ }^{6}$ Behind the defeatist mindset lay not only economic dissatisfaction but also the extreme physical and emotional exhaustion of the population after the wars and disasters of 1914-1921. Moreover, the discontented public criticized Soviet policies and expressed that they had nothing positive to defend. The letter of the peasant woman PetrenkoMakarova to a newspaper was typical:

If ten years have brought nothing good, there will be no success at all. People are devoid of freedom in economic matters, in trade, in religion, in everything. That's their freedom. You are going to fight. But there will be not very many people who wish to sacrifice their lives for such freedom. ${ }^{17}$

Furthermore, wishing defeat on the government, the public greeted a coming war as an opportunity to exact revenge and punish the communists. The worker Belyakov was arrested for his words: "Our country will soon be drawn into war and we shall hang communists then."18 Such dispositions were not limited merely to whispering; they materialized in actions against the local officials. In 1927, the OGPU registered a rise in arson cases from 71 to 78 ; also 914 acts of terrorism in the countryside against party/soviet officials, up from 711 in 1926'; and numerous threats against communists. Of all attacks, 34.6 percent were directed against the local Soviet apparatus, and 29.2 percent targeted $\mathrm{VKPb}$ and Komsomol members. Statistics show that state representatives were the main targets of terrorism: rural communists had to carry guns for protection when working in the fields. Mass actions in the countryside grew from 63 during 1926 and 1927 to 709 in $1928 .{ }^{19}$

16) RGASPI, f. 17, op. 85, d. 19, l. 182.

17) Neizvestnaia Rossiia, $X X$ vek, 3 (Moscow: Istoricheskoe Nasledie, 1993), 224, [1929]; Tsentral'nyi Gosudarstvennyi Arkhiv Sankt-Peterburga (TsGA SPb), f. 1000, op. 11, d. 558, l. 74 . [1927]; GARF, f. 374, op. 27, d. 1211, l. 37; Tsentral'nyi Gosudarstvennyi Arkhiv Istorikopoliticheskikh Dokumentov Sankt-Peterburga (TsGAIPD SPb), f. 24, op. 5, d. 1518, l. 193 [1935].

18) TsGAIPD SPb, f. 24, op. 2v, d. 2486, l. 83, [1937]; d. 2500, l. 7, 182 [1937]; f. 24, op. 1b, d .367, l.64 [1931]; GARF, f. 374, op. 27, d. 1211, ll. 13, 33, 41, 43, 137 [1927]; d. 1210, l. 9; d. 2079, l. 28; RGASPI, f. 17, op. 85, d. 289, ll. 57, 6o, 65, 66 .

19) $S D$, vol. 2, 21, 811, 1031-33, 1038. 
The discontented population saw access to arms in the event of a war as a chance to overthrow the power of Bolsheviks: "We'll wait for war, get some guns, and then talk a little with the Soviet power."20 At a meeting in the village of Ivantsevo, Ivanovoznesensk gubernia, peasants threatened the party representative: "Report to those [at the top] that with the beginning of war when we'll get weapons, the end will come to the Soviet government, [because] we'll turn the weapon against you." The majority met this with applause and cries of "That's right!" 21 Receiving such information from various sources, the authorities saw that the hatred and tensions of the civil war scale lingered in the countryside, surfacing in hostility and excesses.

The police sources, reporting dissent and resistance in society, provoked a lot of criticism from historians. ${ }^{22}$ The OGPU, focused on abnormalities in the wide range of societal responses, sought out disloyalty rather than patriotism. Reporting mass defeatism, the security police officers could consciously (or unconsciously, through specific "perceptual lenses") exaggerate its scale in order to justify their own importance and attract additional funding. Taking the expectations of the authorities into account, they could "doctor" information to show their loyalty and industriousness. Understanding the possible bias of police records, historians verify information by other sources, although they still may be biased in different ways. The party organizers, though responsible for their propaganda's effectiveness, also reported abundant discontent and refusals to fight. Private letters, reviews by the newspapers' editors, and even army information confirm this widespread defeatism and discontent, although we do not have reliable tools to measure its scale. Despite the biased nature of our historical sources, the weight of the evidence taken in context, especially of economic deprivation, suggests massive anger and defeatism. ${ }^{23}$ Ultimately, regardless of the objective level of social animosity, the Soviet leaders, with their inherent fear of the masses, subjectively perceived the defeatist mindset as a threat to their power. As Molotov babbled before his death, the bloody specters of revenge haunted them long after the Civil War. ${ }^{24}$

\footnotetext{
20) RGASPI, f. 17, op. 21, d. 3075, l. 21.

21) GARF, f. 374, op. 27, d. 1215, l. 37, [March 15, 1927].

22) For excellent analysis see Lynne Viola, "Popular Resistance in the Stalinist 1930s: Soliloquy of a Devil's Advocate", Kritika 1.1 (2000) 45-69.

23) I further discuss it in forthcoming book Disenchantment of the Dreamers. Popular Perceptions of Soviet Politics in the 1920s (Palgrave Macmillan, 2013).

24) Sto sorok besed s Molotovym. Iz dnevnika F. Chueva. (Moscow: Terra, 1991) 390, 413.
} 


\title{
Terrorist Attacks
}

In the midst of their alarm over the British demarche and the upsetting domestic situation, the Bolsheviks took another hit-terrorist attacks in Moscow and Leningrad. The emigrants' monarchist organization called the Russian All-Military Union (ROVS) used this moment of crisis as a convenient time to attempt to realize its anti-Communist goals. Earlier, in March 1927, the ROVS deputy chair, General A. Kutepov, called for the start of terrorist attacks against the Soviets. According to a subsequent OGPU investigation, ROVS decided:

\begin{abstract}
In view of the coming intervention against the USSR ... the uprising should be organized in all major cities by the moment of intervention. Active monarchists [emigrants] should penetrate the Soviet territory and take part in uprisings ... . Combat groups secretly sent into the rear of the country should start terror operations against Soviet officials. ${ }^{25}$
\end{abstract}

In view of the interrogative nature of this source, it is difficult to say what was truly behind this statement - the real terrorist plan or the expectations of the interrogator. This growth of emigrants' activism was closely monitored by the OGPU through a counterintelligence game called Operation Trest. ${ }^{26}$ On June 3 and 6, the ROVS groups ${ }^{27}$ committed two explosionsone at the OGPU dormitory in Moscow and another at the party's club in Leningrad. On June 7, the Soviet ambassador, P. L. Voikov, was killed in Warsaw. Voikov had become a target of the lone monarchist Koverda ${ }^{28}$ because, as a chairman of the Ural Soviet, he took part in the execution of Nicholas II and his family in July $1918 .^{29}$

25) Lazar' Fleishman, Vtiskakh provokatsii. Operatsija "Trest" i russkaia zarubezhnaia pechat' (Moscow: NLO, 2003), 178.

26) The goal of this operation (1921-27) was to identify, entrap, and finally eliminate the antiSoviet monarchist underground in the USSR. When the leaders of ROVS learned about Operation Trest in April 1927, they had been demoralized, disbelieved in the possibility of uprisings in the USSR, and only believed in a foreign intervention or terrorism as a destabilizing or at least a symbolical action. See Fleishman, 175.

27) A. Kh. Artuzov's note to D. I. Kursky, September 9, 1927, in Lubianka. Stalin i VChK-GPUOGPU-NKVD. Archiv Stalina. Documenty vysshikh organov partiyinoi i gosudarstvennoi vlasti. Yanvar' 1922-Dekabr' 1936, V. N. Khaustov et al., eds. (Moscow: Materik, 2003), 141.

28) B. S. Koverda, "Pokushenie na polpreda Voikova," Monarkhist, http://monarhist.net/ content/pokushenie-na-polpreda-vojkova, Accessed March 22, 2012.

29) Despite the suppression of these reasons in the press, Voikov's involvement was known to the public in the USSR: GARF, f. 396, op. 5, d. 31, l. 27. 


\section{Turn to Repressions}

Domestic threats - terrorist attacks against the background of the population's anti-Soviet defeatist mood — combined with perceived international threats, heightened the fears of the Soviet leaders and moved them to start mass repressions, which have not yet been described in the literature. ${ }^{30}$

On June 8,1927 , Stalin (then on vacation), responding to the telegram about the murder of Voikov, gave the command to start the repressions. First, he interpreted the assassination as a British provocation and advised caution in reaction to avoid the provocation of war (in a parallel to his later fear in 1941). Second, he suggested:

All the prominent monarchists in our prisons and concentration camps should be immediately declared hostages. First, shoot right away five or ten monarchists and announce that for each assassination attempt we shall shoot a new group of monarchists. The OGPU should be given a directive for sweeping searches and arrests of monarchists and all types of Whiteguardists throughout the USSR, with the goal of their full liquidation by any means. The murder of Voikov gives a reason (osnovanie) for it. We need to reinforce our rear. ${ }^{31}$

When the Politburo received Stalin's telegram, it issued on June 8 appropriate decisions on the commencement of a mass operation. With this decision, the Politburo granted the OGPU the right to issue extrajudicial sentences, including executions:

3. To charge the OGPU with making mass searches and arrests of Whiteguardists.

4. After the governmental announcement, to publish an OGPU message with a reference in it to the made execution of 20 prominent Whiteguardists guilty of crimes against Soviet power.

5. To grant the OGPU and its PP (Plenipotentiary representatives in the regions) the right to issue extrajudicial verdicts, including execution, to those Whiteguardists who are guilty of crimes.

6. To recognize the necessity of strengthening the OGPU with both human and material resources. ... ${ }^{32}$

On June 9, the government communiqué, “To the toilers of the Soviet Union and the world!" blamed the "British government, which is preparing for war

30) The first documents were published in V. P. Danilov, R. T. Manning, L. Viola, eds., Tragediia sovetskoi derevni: Kollektivizatsiia i raskulachivanie. Documenty i materialy. 19271939, 5 vols. (Moscow: ROSSPEN, 1999-2003) (hereafter TSD), vol. 1, 22-24, 77-82.

31) Telegram from Stalin to Molotov, June 8, 1927, Lubianka, 133.

32) Politburo Protocol \# 109, June 8, 1927, RGASPI, f. 17, op. 166, d. 200, l. 1. 
against the Soviet Union," for organizing numerous terrorist attacks, arson, and accidents in industry. The government appealed to the people to defend all of the October Revolution's achievements and entrusted the OGPU with the mission to clear the country of its internal enemies "spies, incendiaries, murderers, the monarchists, and White Guard criminals, together with their allies."33 Fuelled by the deeply entrenched Bolshevik anxieties still lingering from the Civil War, speculation of a foreign threat was the principal rationale behind the launching of purges. ${ }^{34}$ As would become typical of mass operations later, Stalin's initiative was (secretly) legitimized by the Politburo and then put into effect by the government or the OGPU decree. It was the Politburo that supervised the operation and discussed it at almost all meetings from June through July $1927 \cdot{ }^{35}$

Thus, equipped with Article $5^{8}$ and extralegal powers, referring in the press to recent terrorist attacks and international threats, also warning of plots by "imperialist agents" to assassinate Bukharin, Rykov, and Stalin, the OGPU started a mass operation. Its mechanisms followed the model of the Red Terror in September 1918. Then the same methods were utilized after the assassination attempts on the head of the Petrograd ChK, M. S. Uritski, and on V. I. Lenin. ${ }^{36}$ In 1918, the first act of the mass repressions was the shooting of "hostages". Similarly, on June 9, 1927, 20 imprisoned representatives of the old aristocracy were shot without trial following the verdict of the OGPU Collegium.

Stalin's telegram to Molotov and his subsequent instructions to the OGPU head V. R. Menzhinsky from June 23 demonstrate his central role in initiating repressions. The Politburo's protocols give no direct evidence of debates among leaders on the question of repressions or the number of the executed. The rise in the number of victims from 5-10, as Stalin suggested, to 20 might be a sign of his cronies' support and even a zealous effort (at least from the OGPU). Nevertheless, on June 9 Molotov privately reported

33) Pravda, June 9, 1927; Alex G. Cummins, ed., Documents of Soviet History, vol. 4, (Academic International Press, 1995), 208-10.

34) Just one example: on June 25, 1920, F. E. Dzerzhinsky's circular to all local ChKs stated that the war with Poland and General Wrangel justified the need to intensify the struggle against an internal counterrevolution. SD, 1079.

35) RGASPI, f. 17, op. 166, dd. 200-202, 205, 209, Protocols 109-111, 114-5, 117-9.

36) On September 2, 1918 in response to these attempts, five hundred "representatives of overthrown classes" were shot. Between 10,000 and 15,000 people were executed during the two months of the Red Terror. Ronald Hingley, The Russian Secret Police (New York, 1970), 124 . 
to Stalin about some debates in the Politburo: "Few comrades hesitated about the necessity of publishing the government communiqué [regarding repressions], but now everybody agrees that it was in time (kstati) ... . We also take measures to strengthen our rear in various directionsimprovement of relations with the East, inspection in Transcaucasia (by Sergo [Ordzhonikidze]), plus additional measures by the GPU (searches, arrests and subsequent executions of the guilty Whiteguardists), military, etc." ${ }^{37}$ It means that alternative opinions were vocalized in the Politburo, but ultimately the decision on the operation was approved.

In June 1927, a Swedish diplomat reported on the fearful atmosphere in Moscow:

If I should characterize the situation here at present I would say that it is fear that is the most typical feature; the fear of the government for the future and for the consequences of the policy that has been inaugurated against SSSR; the fear of the arrested who, more or less innocent, await their sentences in the prisons or simply wait without ever being sentenced; the fear of those of the population who have not yet been arrested ... ; the fear of all employees that they shall lose their situations and their bread as a result of the financial difficulties; the fear of the peasants of the possibility of war and, lastly, the fear of OGPU that they shall not detect all conspiracies, imagery or real .... As a big black cloud, fear is suspended over the whole society and paralyzing everything. ${ }^{38}$

\section{Extrajudicial Mechanisms}

The acquisition by the OGPU of extrajudicial powers against Whiteguardists, counterrevolutionaries, and spies on June 8, 1927, was part of the systematic partial or total suspension of judicial order from 1917-1941. During the Civil War, extralegal practice, exemplified by the name of the security police-Extraordinary Commission - was the rule. With the end of war, the transformation of the VChK into the GPU on February 6, 1922, aimed at demonstrating a return to normalcy and legality in peacetime. Extralegality, which excluded a number of offenses from the jurisdiction of courts and procuracy, simplifying and speeding repressions, was then formally cancelled by the VTsIK. But two months later it was reintroduced and

37) RGASPI, f. 558, op. 11, d. 767, ll. 35-6. Under "East" Molotov probably meant rebellious Soviet Central Asia, monitored by the OGPU Eastern Department.

38) Letter from M. de Heidenstam to M. Westman, Swedish Ministry for Foreign Affairs, Moscow, June 22, 1927. British Foreign Office, F.O. 371, 1927, vol. 12595, p. 199. 
applied to both political enemies and criminals: on March 9, 1922, against armed bandits (as they often euphemized rebellious peasants and nationals); on October 16, to subdue crimes of the chekists, and in the summer, with the extralegal (or administrative) deportations of intellectuals and anti-Soviet elements. ${ }^{39}$ In the situation of internal disagreement between the chekists and litigators, the Commissar of Justice D. I. Kursky wrote in 1924: "Now the powers of the OGPU are expanded to their limits: the right to confine any 'dangerous' person in a camp up to three years, the right of capital punishment for many offences, the right of the emergency troika in the fight against banditry and so on." 40 Again and again the OGPU received the right to exercise extrajudicial powers, including capital punishment, against counterfeiters in April 1924, smugglers in March 1926, against Buriat-Mongol insurgents in December 1926, against wrecking and diversions in March 1927, ${ }^{41}$ and finally against negligence regarding secret documentation in May 1927. ${ }^{42}$ The regular extrajudicial sweepings of "parasitic elements" (speculators) from Moscow and other major cities were a part of life-in November 1923 (2,400 people), ${ }^{43}$ January-February $1924(1,290),{ }^{44}$ in October $1925(2,400),{ }^{45}$ in March 1926 (2,000), ${ }^{46}$ (note round numbers!) and of hooligans, anti-social, and criminal elements, for example, in 1926, and then in August 1928. ${ }^{47}$ Thus, the extrajudicial repression by means of the OSO (osoboe soveshchanie), the regional OGPU PPs, and special three-man panels for political cases (troiki) formed a central part of Soviet

\footnotetext{
39) Finkel, 304-5.

40) This note reflected disagreement between hard-liners and supporters of more legality, between OGPU and judicial organs in the 1920s. Wheatcroft, "Agency", 21; Shearer; Gabor T. Rittersporn, "Extra-judicial Repression and the Courts in the 1930s," in Reforming Justice in Russia, 1864-1996: Power, Culture, and the Limits of Legal Order, edited by Peter H. Solomon (M.E. Sharpe, 1997); Solomon, Criminal Justice; Eugene Huskey, "Vyshinskii, Krylenko, and the Shaping of the Soviet Legal Order," Slavic Review 46 (1987); O. B. Mozokhin, Pravo na repressii: vnesudebnye polnomochiya organov gosudarstvennoi bezopasnosti (1918-1953) (Moscow, 2006).

41) Lubianka, 115-6, 124, 128, 790, 793-4.

42) Plekhanov, 109, 134-6.

43) Lubianka, 113, 793 .

44) Plekhanov, 511-2; Werth, 135 .

45) Plekhanov, 510, 513 .

46) Lubianka, 113. Due to the preliminary registration of the nepmen, the operation ended in 6 days.

47) Hageloh, 45; Anne E. Gorsuch, Youth in Revolutionary Russia. Enthusiasts, Bohemians, Delinquents (Bloomington: Indiana University Press, 200o), 167-76; Plekhanov, 513.
} 
policing even in peacetime. ${ }^{48}$ Such reliance on extralegal methods was a result of the Bolsheviks' civil-war thinking, which was understandable in conditions when rebellions still continued on the periphery. Between 1923 and 1927, the Red Army and OGPU forces were involved in military operations to secure control in various areas-in the Caucasus (Georgia in 1924; Chechen, Dagestan, Ingushetia, Ossetia in 1925; Dagestan, 1926), Central Asia, and to a smaller scale in Siberia. ${ }^{49}$

In the 1927 operation, in addition to the extrajudicial powers of the security police, the notorious troikas reemerged. On July 1, Procurator of RSFSR N. V. Krylenko suggested that the Politburo create OGPU emergency courts to expedite large numbers of unprocessed cases resulting from the mass operation. These courts would determine the fate of accused anti-Soviets without formal interrogation, prosecution, and defense:

2. Sentences of emergency court are not subject to appeal or cassation and are executed immediately.

3. Emergency courts are not restricted by any judicial procedure and have a right ... to omit any interrogation as well as interrogation of witnesses. Each case should be completed within 24 hours after its receiving by the court.

4. No prosecution or defense.

5. ... Meetings of the emergency courts can be public or closed ...

I think that such a form of punishment will allow the necessary ruthlessness and speediness of the procedure and will throw away the weapon from the hands of counterrevolutionaries used now to blame the government of the working people for extralegality. ${ }^{50}$

Tellingly, Krylenko referred in his note to the VChK Special Emergency Tribunal of Dzerzhinsky from the Civil War period as a model. At the end of the note, Krylenko referred to Western charges. The shooting of the hostages without a trial caused heated protests in the West. For example, British socialists protested in their telegram to the government chair A. I. Rykov. Foreign minister G. Chicherin reported condemnation abroad at the end of June and proposed to stop the repressions. ${ }^{51}$ Soviet officials Rykov, Krylenko, ${ }^{52}$ and later Stalin (on November 5,1927 ) labored to justify the

\footnotetext{
48) Hagenloh, 33, 42 .

49) Hoffmann, Cultivating the Masses, 263-4; Lubianka, 109-10, 119-21.

50) Lubianka, 137-8, 796.

51) Michael Reiman, The Birth of Stalinism. The USSR on the Eve of the "Second Revolution,"

(Bloomington: Indiana University Press, 1987), 15-17.

52) Izvestia, July 29, 1927, p. 3 .
} 
executions in interviews to foreign correspondents and delegations. As evident in the Krylenko's note, international pressure made the authorities decorate arbitrariness with a façade of legality, which later was realized in the September-October 1927 show trials. ${ }^{53}$

Alhough Krylenko's suggestion was not formally accepted in the summer of 1927, such extrajudicial troikas did function by default in gubernia GPUs ${ }^{54}$ - certainly in the Far East Republic, ${ }^{55}$ and in Belorussia-one more example of tenuous central control and the self-reproducing nature of extralegality in the system of power. From Belorussia, a deputy head of the OGPU Counterintelligence department, R. A. Pilliar, informed Menzhinsky in a letter from July 13, 1927:

Last Saturday I conducted the first meeting of the judicial troika. I sentenced 29 people to death. I sent the protocol and the files to the GPU with the courier. They approved all verdicts except one ... . The protocol passed [there] through apparatus troika (Artuzov, Deribas, Feldman) ... . Such a procedure may be cancelled, as we are quite capable of taking responsibility for the degree of punishment on ourselves. ${ }^{56}$

Local officials understood that their power to carry out sentences of the wartime period was back. In summer 1927, the Politburo authorized local OGPUs to carry out summary repressions, including executions, of people accused of political crimes or banditry. ${ }^{57}$ The level of extrajudicial repressions in localities increased, especially in potentially rebellious areas like Siberia, the North Caucasus, ${ }^{58}$ and in the border areas in order to prevent there possible collaboration in the event of war. Geographical application of extreme measures suggests that the government was unsure in its control almost everywhere beyond the Central European Russia.

Later, extralegality continued to expand. Summer operation was followed by another mass operation in October 1927 against private traders, who offered peasants higher prices for grain and thus "undermined" state procurements. During this operation, extrajudicial powers were again granted to the security police: it conducted these arrests without

\footnotetext{
53) Lubianka, 796, 143 .

54) Lubianka, 121, 793. The troika in Dagestan sentenced 52 people to death in 1926.

55) Created on June 29. Plekhanov, $136,138$.

56) TsA FSB, f. 2, op. 5, d. 5, ll. 173-4, cit. in Plekhanov, 130; The verdicts of the republic-level troikas were to be sanctioned by the OGPU Special Board in Moscow.

57) Hagenloh, 42, 51.

58) Wheatcroft, "Evdokimov," 30.
} 
requesting the prosecutor's permission, which was commonly necessary under Soviet law. The operations against grain and leather "speculators" continued through the next spring, resulting in 7,894 arrests. Another wave of repressions involving extralegal practices took place in the winter of 1927-28 during the "extraordinary" grain procurement campaign in the countryside when cases of the arrested were processed without due court procedure through the OSO and the troikas. ${ }^{59}$ Together with 7,086 peasants arrested, thousands of hesitant or dissident local party officials were dismissed and prosecuted, for example, 1,157 people in Ural oblast'.60 Approximately 16,00o people were arrested from December 1927 to April $1928 .{ }^{61}$

These "extraordinary measures" were halted by the April 1928 Central Committee Plenum, but were reintroduced in October 1929 and in February 1930 in several areas to deal with "de-kulakization." Troikas were reestablished after a half-year pause in autumn 1933 everywhere except the Central European Russia, ${ }^{62}$ then in the spring of 1935 , and again in July 1937 as a weapon of the Great Terror. Besides troikas, other extrajudicial powers, such as the right to deport and execute people without court, were granted to the NKVD in 1934, after the murder of S. M. Kirov. Those charged with terrorism were deprived of the rights of defense, the privileges of appeal, and sentenced to be shot immediately after the decision by the Military Tribunal (a belated realization of Krylenko's suggestion). Thus, in the $1920 \mathrm{~s}$ and 1930s, we see a persistent pattern of cessation and reemergence of the extrajudicial power of the OGPU toward specific groups and offences. Actually the "state of exception" became the rule.

The suspension of legal procedure historically is a core of politics Giorgio Agamben called a "state of exception" - when a government, facing an emergency situation, views legality as too cumbersome and sluggish. The state of exception is by definition- d'état de siège (France), military order (United States), martial law (United Kingdom) — bound to a war situation.

59) Roberta T. Manning, "The Rise and Fall of 'the Extraordinary Measures,' January-June 1928: Towards a Reexamination of the Onset of the Stalin Revolution," The Carl Beck Papers in Russian and East-European Studies, \# 1504 (January 2001): 4-5, 8-9, 13.

60) V. P. Danilov, et al. eds., Kak lomali NEP: stenogrammy plenumov TsK VKP (b) 1928-1929 gg. (Moscow, 2000) vol. 2, 14; vol. 1, 25 .

61) TSD, vol. 1, p. 27, 86, 100-2, 231; SD, vol. 2, p. 21, 1036; Elena Osokina, Our Daily Bread. Socialist Distribution and the Art of Survival in Stalin's Russia, 1927-1941 (Armonk, NY, 2001), 23; Manning, 14 .

62) Shearer, 118-120. 
Originating from the French Revolution, after 1791, however, a state of exception gradually emancipated itself "from the wartime situation to which it originally bound, in order to be used as an extraordinary police measure to cope with internal ... disorder, thus changing from a real, or military state of siege to fictitious, or political one." ${ }^{63}$ Throughout history, the application of the state of exception expanded: from military strongholds in France, to municipalities in the interior; later, wartime politics extended into the civil sphere and into peacetime; and, finally, when the state of exception was introduced in France in January 1924 to save the franc, military emergency ceded its place to economic emergency. ${ }^{64}$ During the First World War, a state of exception was declared in the majority of belligerent countries. Immediately after the war, as executive powers expanded, the emergency "instruments of government became lasting peacetime institutions" - and not just in Russia. Thus the establishment of the state of exception was a general European phenomenon in the interwar period. But while postwar European countries limited the full application of wartime methods, the Soviet regime of class warfare was an example where extralegal violence, as a provisional and exceptional measure, was institutionalized as a technique of government. The centrality of extralegality and other wartime practices in Soviet politics reveals the mode of emergency, which dominated in relations between the regime and society.

\section{Targets}

In public pronouncements, Stalin presented this repression, repeating Maximilien Robespierre, as a necessary measure of self-defense and an instrument to strengthen the USSR in face of a war, along with other means, such as the solidarity campaign abroad, vigilance at home, military reform, and liquidation of the party opposition: ${ }^{65}$

Our mission is to strengthen our rear and cleanse it of dross [skverna], including terrorists and the incendiaries who set fire to our mills and factories because the defense of our country is impossible without a strong, revolutionary rear. ${ }^{66}$

\footnotetext{
63) Giorgio Agamben, State of Exception (Stanford University Press, 2005), 5.

64) Ibid, 9 .

65) Stalin to Molotov, June 15, 18, 1927. RGASPI, f. 558, op. 11, d. 767, ll. 40, 41.

66) I. V. Stalin, "Zametki na sovremennye temy," Sochinenia, (Moscow, 1953), vol. 9, 327-330;

Pravda, July 28, 1927. Translation see in Documents of Soviet History, vol. 4, 211-28.
} 
The targets of the operation, according to Stalin's instructions from June 8 and the Politburo decision, were "monarchists" and "Whiteguardists." However, that does not mean that only the members of monarchist organizations and former White officers were persecuted. ${ }^{67}$ Among exiled "Whiteguardists," for example, was the unfortunate L. V. Kiriakova (together with her 18-year-old daughter), who hosted a literary salon in Omsk under Kolchak regime and later in Moscow. ${ }^{68}$ In Bolshevik language any disloyal person could be labeled a "Whiteguardist." 69 Thinking in Civil War terms, even in the 1930s the Stalinists continued branding any enemies or disloyal persons as "White Guards."70 Stalinists still saw themselves as engaged in a war with the population. The term "mass operation" also came from the Civil War when chekists used it to denote one-time campaigns, "sweeps aimed at 'dangerous' individuals". ${ }^{71}$ Because arrests were preventive and aimed not at actual crimes that had been committed, but at potential "crimes," their mechanism can be compared, as A. M. Plekhanov does, with a kind of seine thrown for "big fish" (spies, terrorists, opponents of Soviet power), and they were also instrument used to check the agent's information, and to recruit new agents among the arrested. ${ }^{72}$

To secure himself, Menzhinsky sought instructions on whom the targets actually were, how many to arrest, and how many were supposed to be shot, when on June 19 he appealed to Stalin and the Politburo, "The OGPU intends to limit the quantity of the executed by a relatively small number, turning over the cases of the main spy organizations for public trial."73 In response Stalin instructed about the targets and methods of operation:

67) As Paul R. Gregory believes in his Terror by Quota. State Security from Lenin to Stalin (New Haven: Yale University Press, 2009), 30.

68) V. K. Vinogradov, "Zelenaia lampa," Nezavisimaia Gazeta, April 20, 1994, p. 5.

69) Similarly, the ideological meanings of terms 'working class,' 'petit bourgeoisie,' 'kulak' are discussed by Donald Raleigh "Languages of Power: How the Saratov Bolsheviks Imagined Their Enemies," Slavic Review 57, no. 2 (Summer, 1998): 338; Lynne Viola, "The Peasants' Kulak. Social Identities and Moral Economy in the Soviet Countryside in the 1920s," Canadian Slavonic Papers 42, no. 4 (2000). In parallel, in the 1920s, the notion of "counterrevolutionary crime" continued to broaden. Werth, "A State against Its People", 135.

70) J. Arch Getty and Oleg V. Naumov, The Road to Terror: Stalin and the Self-destruction of the Bolsheviks, 1932-1939, translations by Benjamin Sher (New Haven: Yale University Press, 1999), 16.

71) Hagenloh, 51.

72) Plekhanov, 313 .

73) Danilov, Introduction, TSD, vol. 1, 24. 
My personal opinion: (1) The agents of London are embedded in the country deeper than it appears ... ; (2) Sweeping arrests should be used to destroy English espionage ties, to recruit new agents among the arrested for Artuzov's agency [Counterintelligence], and to develop a network of voluntary OGPU informers among the youth; (3) it would be good to stage one or two show trials of English spies, in order to use it in England and Europe; ... (6) pay special attention to espionage in the military, aviation and navy. ${ }^{74}$

Thus, in addition to "Whiteguardists," the targets now included spies. In combination with the industrial "wreckers" - a category that had already been specified in Stalin's address to the OGPU from January 13, 1927 ${ }^{75}$ - the core set of Stalin's chimeras was complete. It was Stalin who had determined the enemies.

Since 1927, espionage had become a regular topic of the OGPU agenda. The number of people accused of espionage grew from 3,670 in 1926 to 5,985 in $1927 \cdot{ }^{76}$ Three show spy trials were organized to satisfy Stalin's wish. At the beginning of July, the OGPU "discovered" a spy organization in Leningrad with a certain A. I. Goyer at the head. Twenty-six ex-navy officers and employees in the civil and military institutions were arrested. During the September show trial in Leningrad, nine were condemned to death. ${ }^{77}$ Another trial took place in Leningrad on September 23-24 for five members of ROVS involved in a series of explosions in June $1927 .{ }^{78}$ The third show trial for alleged British spies was staged on October 21-24 in Moscow. ${ }^{79}$ All death verdicts were approved by the Politburo. ${ }^{80}$ Provincial chekists followed the model of the center. "In the second half of 1926, local [Siberian] chekists initiated not a single espionage case, but since 1927 [the Siberian OGPU] office hastily fabricated espionage cases without any care about their truth ... for example, the case of exiled A. P. Pochinkov in June 1927 or

74) Telegram from June 23, 1927; Lubianka, 135 .

75) Lubianka, 125. Since 1927 "wrecking" became a regular topic in the Politburo agenda. Gregory, 122.

76) A. Yu. Epikhin, O. B. Mozokhin, VChK-OGPU v bor'be s korruptsiei v gody novoi èkonomicheskoi politiki, 1921-28 (Moscow: Kuchkovo Pole, 2007), 274-301.

77) Izvestia, August 31, 1927; Pravda, September 7-14, 1927.

78) A. Kh. Artuzov's note to D. I. Kursky on case of terrorists, September 9, 1927, and Politburo TsK VKPb decision, September 15, 1927, in Lubianka, 139-41; Pravda, September 25, 1927; British Foreign Office, 1927, F.O. 371, vol. 12593, p. 135, 138.

79) Pravda, October 18, 1927; Protocol of Politburo, October 21, 1927, RGASPI, f. 17, op. 162, d. 5, l. 119, published in Lubianka, 143; The Times, October 18, 1927; British Foreign Office, 1927, F.O. 371, vol. 12593, p. 204.

80) Politburo protocols from September 1, 12, 21, RGASPI, f. 17, op. 162, d. 5, l. 93, $101,119$. 
of former miner M. F. Romanov in September 1927." ${ }^{11}$ Again, the increase in the number of trials from one or two, as Stalin had ordered, to three demonstrates the OGPU fervor.

\section{Widening of Repressions}

In contrast to other operations of the 1920s directed against specific groups, such as the nepmen, intelligentsia, the mountaineers of Dagestan, or hooligans, the summer mass operation was diffuse and targeted a wide range of political opponents: spies, noblemen, White officers and soldiers, landowners, priests, the old intelligentsia, ${ }^{82}$ former members of "anti-Soviet" parties, and peasants. Thomas Preston, the British consul in Leningrad, reported, "The recent arrests have not been confined to any particular class or section of the population. Bourgeois, officers of the ancient regime, domestic servants, concierges, members of the Communist Party, and even agents of the OGPU itself-all suffering alike." ${ }^{83}$ Cossacks were another special target of the operation in the North Caucuses and Siberia. ${ }^{84}$ Ultimately, the victims of the operation were any "anti-Soviet elements", who committed no crimes, but deemed to be dangerous to the regime. Fateful consequences followed arrests of the clergy: Roman Catholic, Muslim, and Orthodox, although mostly the followers of Patriarch Tikhon. This new wave of repression against priests, together with other pressures from the OGPU, might have acted as the last straw that caused Metropolitan Sergii to sign on July 29 the Declaration of the church's recognition of Soviet power. ${ }^{85}$ Tellingly, calling on the believers to support the USSR, the Declaration referred to threats of war, boycott, and terrorist attacks. This document emblemized the subjugation of church to state.

The largest group attacked, however, was the peasantry: according to V. P. Danilov, about nine-tenth of the repressed constituency. Instructing the gubernias' OGPU bosses on July 6, Yagoda, the deputy commissar of the

81) A. G. Tepliakov, "Nepronitzaemye nedra". VChK-OGPU v Sibiri. 1918-1929 gg. (Moscow, 2007), 194.

82) Vinogradov, "Zelenaia Lampa".

83) British Foreign Office, F.O. 371, 1927, vol. 12595, p. 218.

84) RGASPI, f. 17, op. 85, d. 289, l. 37-40.

85) Tikhonovtsy resisted acknowledging Soviet power. L. A. Boeva, “Osobennaia kasta." VChKOGPU i ukreplenie kommunisticheskogo regima v gody NEPa, (Moscow: AIRO-XXI, 2009), 153. 
OGPU, presented defeatism as the reason for the "Operation against the village counterrevolution":

In some areas of the USSR, especially in the Ukraine, the North Caucasus, Belorussia, Trans-Caucasia, and the Far East, we have in the village certain elements that the foreign counterrevolution may rely on in this moment of external conflict ... Most recently, in connection with the international threat to the USSR, the aforementioned regions and other localities registered a mass of defeatist agitation, appeals for desertion in the event of war, and for attacks against communists and the Soviet elements. ${ }^{86}$

This OGPU Instruction $N^{\circ} 131$ ordered to suppress the growing activity of the kulaks, Whiteguardists, Petluraists, former members of anti-Soviet parties, clergy, and all who agitated for pogroms, Peasant Unions, and defeatism. ${ }^{87}$ In this context, the main concern was elimination the potential of the "fifth column" behind the imagined frontlines of the coming war.

According to documents in our possession, the OGPU eventually arrested too many people and their cases remained unprocessed. The Workers and Peasants Inspection (Rabkrin) assessing the justice agencies in 1927 reported a "prison crisis" 88 as the prisons were overcrowded and the courts had become congested. Foreign observers reported from Leningrad in the beginning of June: "Only in the last few days the Che-Ka has arrested more than 2,000 people and does not know where to put them as the prisons are full." ${ }^{9}$ This excessive number of prisoners was the reason why, on June 30, the Politburo decided to stop the mass operation and to concentrate instead on accelerated investigations of those already arrested. ${ }^{90}$ "The reported numbers [of the arrested] should be considered to be excessive." 91 As an exception, the Politburo allowed the continuation of arrests in Georgia, ${ }^{92}$ with a focus on the most active elements. This recoil in policy displays an

86) Tsentral'nyi Archiv FSB (TsA FSB), f. 66, op. 1, d. 174, l. 224, cit. in Danilov, Introduction, $T S D$, vol. 1, 25-6.

87) TsA FSB, f. 66, op. 1, d. 172, 1. 522, quoted in V. K. Vinogradov, "Informatsionnye materialy OGPU 1923-29 gg." SD, vol. 2, 43.

88) Peter H. Solomon, Soviet Criminal Justice under Stalin (Cambridge, 1996), 66-7. The prison crisis persisted in 1928 (Plekhanov, 146) and also in 1933 (Shearer, 136-7).

89) British Foreign Office, 1927, F.O. 371, vol. 12593, p. 71.

90) Krylenko's suggestion about emergency courts was a response to this request.

91) Lubianka, 136.

92) On June 28-29, 1927 five commanders of Trans-Caucasian Red Army were arrested and condemned to death on charges of preparation of rebellion to remove all Stalinists from the Trans-Caucasian government. British Foreign Office, 1927, F.O. 371, vol. 12595, p. 232. 
emergence of more moderate views on repressions and mobilization within the Politburo. Soon followed Bukharin's and Chicherin's speeches at the TsK and TsKK Plenum against war frenzy and anti-wrecking hysteria in the press and resulting Politburo decision from July 4 initiated by Bukharin and Rykov: "The press should not inflame any ... occurrences inside the country, like arson, attempts upon the life, etc., but report them without exaggeration. ${ }^{\text {93 }}$ Most likely, international criticism of the aggressive propaganda campaign and repressions in the USSR, together with absence of war, convinced moderates in the government to retreat. However, the decision on the cessation of mass operation was not realized until the end of July and the local press continued its mobilizing campaign.

On July 1, the OGPU submitted very fragmented statistics to Molotov: $35^{\circ}$ people had been arrested in Azerbaijan since May 1927. From January 1927, 614 people had been arrested and 242 exiled in Georgia and 30 people in Armenia, where the OGPU still planned to arrest 200-250 more people in July. ${ }^{94}$ In Samara, 62 people were arrested on June 6. In Siberia on June 15, $55^{6}$ people were searched and 166 arrested. Despite the Politburo's decision, however, arrests continued in July not only in Georgia, but in the Ukraine, North Caucasus, Trans-Caucasus, Belorussia, and the Far East. In the North Caucasus, 1,519 people were arrested and 1,500 searched on July 28; in Belorussia, 602 were arrested and 830 searched; in the Ukraine 1,225 people were arrested. ${ }^{95}$ The war threat was still being used as a justification for continuing repressions. For example, E. G. Evdokimov, the head of the North Caucasus OGPU, requested on October 8 the Party Kraikom to approve the death sentence of 79 Whiteguardists in the Shakhty-Donetsk okrug. He emphasized that these Cossacks would be "a real force against us, in the event of an international conflict" and that it was, therefore, "very important to destroy them." As S. Wheatcroft noted, this attitude and argument were to reemerge in 1937-38 together with the "album method" that Evdokimov introduced, formatting his request into a collection of pasted photographs of the accused and the charges against them to streamline the indictment process. ${ }^{96}$

\footnotetext{
93) RGASPI, f. 17, op. 162, d. 5, ll. 63-4; f. 17, op. 2, d. 288, 1l. 60-6.

94) RGASPI, f. 17, op. 85, d. 288 , l. 100.

95) TsA FSB, f. 2, op. 5, d. 5, ll. 65, 70, 83, cit. in Plekhanov, p. 313-4; In Samara 7 people were arrested to recruit new informers and 2 to mask the algorithm of repressions (!).

96) Wheatrcroft, "Evdokimov," 30.
} 
The reported results of the operation were vague: "defeatism and antiSoviet agitation weakened"97 R. A. Pilliar reported to Menzhinsky in July 13, 1927:

3. The operation purged some anti-Soviet elements and attacked the anti-Soviet public ... . 4. It lifted moods among the workers, Red Army soldiers, loyal employees, and the pro-Soviet strata of the village ... . The operation revealed several counterrevolutionary groups in the city and in the village ... . The urban antiSoviet public, combining legal and illegal methods, stirs the village ... . The operation was a kind of exam for the OGPU and our border guards. They were excellent. It is too sad that Poles will kill them all in the first days of the war. ${ }^{98}$

The operation failed to uncover connections between the counterrevolutionary organizations inside the country and the foreign intelligence service, which chekists suspected, but it did succeed in recruiting new informants. Yagoda recognized in his July 5 letter to OGPU departments that the operation had attacked predominantly "old" cadres of the counterrevolution, but had not unearthed the young anti-Soviet underground. He called for more efforts in uncovering young cadres of monarchists and terrorists. ${ }^{99}$ Menzhinsky wrote to the Politburo on July 19: "The operation against monarchist and Whiteguardist circles had modest results. Few active monarchist groups were unearthed in Belorussia, in Smolensk, Moscow, Leningrad, etc."100

Limited information is available to historians estimating the total number of people arrested and executed during this mass operation. Menzhinsky's report to the Politburo on July 21, 1927, was not accessible for the author in the FSB archive. V. K. Vinogradov, who saw it, reports at least 20,000 searches and 9,000 arrests in June alone. ${ }^{101}$ Rumors referred to 4,000 arrested in Moscow, and the British mission reported the same number in Leningrad. ${ }^{102}$ A good analyst, the Norwegian ambassador Mr. Urbye, reported about 10,000-12,000 arrested in June. He also described numerous house searches without arrests, probably hunts for traces of anti-Soviet plots. Defeatist agitation "often figured among accusations entailing death

\footnotetext{
97) $S D$, vol. 2, p. 628, [March 1928]; RGASPI, f. 17, op. 85, d. 289, l. 12, 28.

98) TsA FSB, f. 2, op. 5 , d. 5 , ll. 124-5; 172-3, cit. in Plekhanov, 314.

99) Yagoda's July 2 order and July 5 letter to OGPU departments. Plekhanov, 244, 315.

100) Vinogradov, "Zelenaia lampa”.

101) Ibid.

102) RGASPI, f. 17, op. 85, d. 289, l. 12; British Foreign Office, 1927, F.O. 371, vol. 12595, p. 218.
} 
sentences."103 Summing up the minimal 10,000 arrested in June with the reported 3,345 people arrested in July in the Ukraine, North-Caucasus, and Belorussia, we reach at least 13,345 people arrested in this operation during June and July. Even with this incomplete data, the number of arrests was almost twice as many as the 7,086 peasants arrested during the "extraordinary" measures in January-April of 1928. To place these numbers into a broader context, the total number of people arrested by the OGPU for political crimes in 1927 was about 49,000 (31,000 in 1926). ${ }^{104}$ If we assume that all 13,345 arrested in the operation were accused in political crimes, then this number would be almost half of the political charges $(27,360)$ in 1927 (21,375 people accused of counterrevolutionary crimes and 5,985 of espionage ${ }^{105}$ ). We do not know how many were executed in the operation, but 1927 saw more than double the growth in death sentences $(2,363) \cdot{ }^{106}$ Even incomplete data shows that the summer operation was a significant increase in the context of the general progression of repressions in the period. The scale places this mass operation beyond previous operations of the 1920s, which targeted usually no more than 2,400 victims, and indicates a new for peacetime repressive practice of sweeping large and vaguely defined groups of the population.

This operation covered the entire country. It made a strong impression upon the population in the capitals, the Ukraine, the Central area, Northwest, Kuban, Dagestan, Georgia, and Siberia. The OGPU reported that the poor villagers supported the arrests of kulaks. Svodki also noted a common fear: "It's frightening to live in our times. Every night you expect to be arrested." Ivan Rusanov from Shakhty okrug, Ukraine, explained that the communists became scared of war and arrested the people in the village, anticipating rebellion in the case of war. ${ }^{107}$

One of the outcomes of the Bolshevik's turn to repressive politics was a more formalized and regular surveillance of the countryside. Hoffmann pointed to the connection between war scare and greater surveillance of

103) G. T. Rittersporn, "The Catastrophe, the Millennium, and Popular Mood in the USSR," in The Soviet Union - a Popular State? Studies on Popular Opinion in the USSR (St. Petersburg: Evropeiskii Dom, 2003), 56 .

104) Getty and Naumov, 588. The share of political arrests see in Hagenloh, 50, and Gregory, 18.

105) Epikhin and Mozokhin, 274-301. Dvizhenie obviniaemyh privlechennyh po sledstvennym delam za 1926, 1927, 1928 gody.

106) Ibid.

107) OGPU svodka about peasants' attitude to the arrests, July 23, 1927, TSD, vol. 1, 77-82. 
internal enemies, which reveals party fear of simultaneous attack. ${ }^{108}$ As early as 1919, F. E. Dzerzhinsky pushed the VChK "to infiltrate the countryside to collect information in order to signal about the danger in time."109 In February 1924, 1926, May 1927, and again in the summer of 1927 the OGPU required from its gubernia organs more regular information on anti-Soviet moods in the countryside. As a result of this increased concern and summer mass operation, the mechanisms of surveillance were considerably improved by the fall of 1927: the volume of reviews increased, and they became more focused on political, rather than economic, information. The number of informers in the village, mostly from the local intelligentsia, increased by January 1928 to $8,596 .{ }^{110}$ Moreover, to avoid confusion about the targets of the future mass operations, the preliminary registration (uchet) of the rural anti-Soviet "elements" commenced in 1927. As a part of a Soviet cataloguing practice, which started at least in 1921, this uchet followed the model of earlier registrations of particular categories within the population such as the nepmen, intelligentsia, Whiteguardists, and former employees of the tsarist police. In the Ukraine, 1,394 former insurgents and 5,700 participants of "political banditry" were registered. The total number of classified people rose from 30,000 to about 72,000 in that year, ${ }^{111}$ amounting to $10-15$ percent of the entire adult population in the $1930{ }^{112}$ The local OGPU reported: "[We] registered the suspicious elements to keep an eye on them in the future."113 Such registration of suspicious elements prepared the security organs for quick and focused mass arrests in the future. Thus, in the 1920s, the system of surveillance, social cataloguing, and repression $^{114}$ was gradually built as a technique of power. Together with the increase in the number of victims of mass operations, this turn to more

\footnotetext{
108) Hoffmann, Cultivating the Masses, 207.

109) Dzerzhinsky's notes on functions of the VChK/OGPU, RGASPI, f. 76, op. 3, d. 79, l. 15.

110) Plekhanov, 487. In 1924 The OGPU had total 10,00o paid informers in the country ( 518 in Moscow), but at the end of the 1920s, 10,000 informers only in Moscow. V. S. Izmozik, Glaza i Ushi Regima, (St-Petersburg, 1995), 117.

111) $S D$, vol. 2, p. 8, 43, 626; Werth, "A State against Its People," 140. Izmozik stated 99,68o as registered by the OGPU Secret Department in 1924, Izmozik, 120. Dzerzhinsky's circular on compiling the nepmen list from September 22, 1922 see in Plekhanov, 591-2.

112) Holquist, "State Violence", 154.

113) TsGA SPb, f. 4370, op. 5, d. 4, l. 314.

114) Those same lists, compiled in the 1920s, were used for repressions in 1937-38. Holquist, "State Violence," 134, 144, 154. About the 1930s see Shearer, 158-80.
} 
formal and all-embracing registration in 1927 evidences a new level in the development of state violence.

\section{Conclusion}

The events of 1927 had crucial importance in the emergence of the Stalinist mode of rule. Facing the combination of a perceived danger of war and real internal social hostility, in a situation of economic crisis, the Bolsheviks tried to secure the regime by turning from concessions to repressions against a broad range of unreliable groups of the population and applying extralegal methods. Despite the presence of moderate opinions in the Politburo, by 1927 Stalin had accumulated enough influence, so that his paranoid worldview, fueled by the OGPU and often shared by his comrades in arms, became more vocalized in the Politburo that approved his repressive initiatives.

The summer operation was a part of the progression of social and political repressions. Except for scale and lethality, many elements of the 1927 mass operation had much in common with the 1930s repressions: the preemptive character, the initiative of Stalin in its organization, the accompanying mass political mobilization, the spectrum of targets, extrajudicial practice, the murder of a party official as a trigger, the overfulfillment of Stalin's instructions, and even the quotas of arrests (the case of Armenia). The 1927 episode also highlights the perceived threat of war as a crucial motivating factor in repressions, both in the Great Terror and in the 1920 . Though some scholars ignore the role of a foreign threat as a vital factor in repression politics, ${ }^{115}$ the majority acknowledge this element. ${ }^{116}$ O. Khlevnyuk showed fear of an inner "fifth column" uprising in the event of foreign intervention as the major driving force behind the Great Terror. ${ }^{117}$ This article draws attention to two elements among others that were

\footnotetext{
115) Iorg Baberovsky, Krasnyi terror. Istoria stalinisma (Moscow: ROSSPEN, 2007); The Black Book of Communism.

116) Robert Thurston, Life and Terror, in Stalin's Russia. 1934-1941 (New Haven: Yale University Press, 1996), 223; Hoffmann, Stalinism, 86; Theodore von Laue, Why Lenin? Why Stalin? Why Gorbachev? The Rise and Fall of the Soviet System (New York, 1993); V. Khaustov and L. Samuelson, Stalin, NKVD i repressii 1936-1938 gg. (Moscow: ROSSPEN, 2010). 117) Oleg Khlevnyuk, "The Objectives of the Great Terror, 1937-1938," in Hoffmann, Stalinism, 102-3.
} 
crucial in state violence in the 1920s and 1930s: a war alert and extralegality, indicating a wartime emergency method of governing in peacetime.

This episode sheds light on the nature of the warlike relations between the Soviet state and society and the Bolsheviks' paroxysmal attempts to secure control over society. The government dealt with crisis as if it were still engaged in a kind of civil war and, in such a paradigm, it was natural for the Bolsheviks to resort to force without any legal restrictions. As a result, they reproduced a permanent state of emergency, as in the war scares of 1923 and 1927. Massively applying wartime methods to manage societyextralegality, mass repressions, mass mobilizations, expropriations, surveillance, and cataloguing-Soviet regime can be defined as a total war regime. Such a state, in its endeavor to fashion a perfect society, can be defined "as establishing, by means of the state of exception, of a legal civil war that allows for the physical elimination not only of political adversaries, but of entire categories of citizens who for some reason cannot be integrated into the political system."118

\footnotetext{
118) Agamben, 2.
} 